\title{
Chlamydia trachomatis among women with normal and abnormal cervical smears in Lagos, Nigeria
}

\author{
Maymunah Adeshola Adegbesan-Omilabu ${ }^{1}$, Kehinde Sharafadeen Okunade ${ }^{{ }^{*}}$, \\ Ayotunde Ayodeji Oluwole ${ }^{1}$, Abidoye Gbadegesin ${ }^{2}$, Sunday Aremu Omilabu ${ }^{3}$
}

\author{
${ }^{1}$ Department of Obstetrics \& Gynaecology, Lagos University Teaching Hospital (LUTH), Lagos, Nigeria \\ ${ }^{2}$ Department of Obstetrics \& Gynaecology, Lagos State University Teaching Hospital (LASUTH), Lagos, Nigeria \\ ${ }^{3}$ Department of Microbiology \& Virology, College of Medicine, University of Lagos, Nigeria
}

Received: 23 May 2014

Accepted: 10 June 2014

\section{*Correspondence:}

Dr. Kehinde Sharafadeen Okunade,

E-mail: kokokenny@yahoo.com,kehindeokunade@gmail.com

(C) 2014 Adegbesan-Omilabu MA et al. This is an open-access article distributed under the terms of the Creative Commons Attribution Non-Commercial License, which permits unrestricted non-commercial use, distribution, and reproduction in any medium, provided the original work is properly cited.

\begin{abstract}
Background: Chlamydia trachomatis is one of the most common sexually transmitted disease agents. Cervical intraepithelial neoplasia (CIN) has been independently associated with serological evidence of chlamydial infection. This study therefore was aimed to determine the prevalence of C. trachomatis and the association between Chlamydia trachomatis infection and cervical intra-epithelial lesion.

Methods: It is a cross-sectional case control study carried out at the Lagos University Teaching Hospital (LUTH) with the study participants selected into 2 groups: the case group (women with abnormal smears) and the control group (women with normal Pap smear). Relevant information was obtained using a structured intervieweradministered questionnaire. Endocervical swab sample was collected and analysed by Polymerase Chain Reaction (PCR) test. Data analysis was done using Epi-Info statistical package (version 3.4.3).

Results: The overall prevalence of $\mathrm{C}$. trachomatis was $27.7 \%$ with a decreasing trend noted with age $(\mathrm{P}<0.05)$. The majority of women with $\mathrm{C}$. trachomatis were in the reproductive age group of $25-45$ years. $50 \%$ of women with abnormal smears were positive for $\mathrm{C}$. trachomatis, compared to only $16.7 \%$ of the controls $\left(\mathrm{X}^{2}=10.95 ; \mathrm{P}=0.001\right)$. There was no statistically significant association between prevalence of $\mathrm{C}$. trachomatis and cervical cytological types $\left(\mathrm{X}^{2}=1.892 ; \mathrm{P}=0.595\right)$

Conclusions: The study revealed an association between Chlamydia trachomatis and precancerous lesions of the cervix. Routine screening and treatment of sexually active adolescents and women in the reproductive age group is recommended as an indirect measure to reducing the incidence of cervical cancer in Nigeria.
\end{abstract}

Keywords: Chlamydia trachomatis, Cervical intra-epithelial lesion, PCR, Cervical cancer

\section{INTRODUCTION}

Cervical cancer is the second most common cancer among women in the developing countries and the seventh most common cancer in the developed countries. ${ }^{1}$ Over 500000 new cases are seen yearly ${ }^{1}$ with over $80 \%$ of them being from the developing countries. ${ }^{1-3}$ Worldwide, it claims the lives of 300,000 women annually with over $80 \%$ coming from the developing countries. ${ }^{1}$ It is the most common gynecological cancer and a leading cause of cancer death in women in Nigeria. ${ }^{4}$

Persistence infection with high risk Human Papillomavirus (HPV) types is now known to be a necessary cause of cervical cancer; however, infection with HPV alone however is not sufficient to cause cervical cancer. ${ }^{5,6}$ Other sexually transmitted infections such as Chlamydia trachomatis and Neisseria gonorrhea may increase the risk of cervical cancer in a woman with 
HPV infection. ${ }^{7}$ Several studies in Nigeria have demonstrated an association between cervical cancer and C. trachomatis infection ${ }^{7,8-14}$ as it may possibly be one of the co-factors that promote the oncogenic potential of the HPV. ${ }^{15-17}$

Chlamydia trachomatis, an obligate intracellular Gram negative bacterium, is one of the most common sexually transmitted disease agents. Its worldwide prevalence is $20-40 \%^{18-20}$ with several studies in Nigeria showing equally high prevalence among the women in the reproductive age $\operatorname{group}^{8,10}$ antenatal women ${ }^{9,11}$ and individual with sexually transmitted infection in Nigeria. ${ }^{8,12-14}$ Koutsky et al. ${ }^{6}$ found that Cervical Intraepithelial Neoplasia (CIN), after adjustment for HPV status, was independently associated with serological evidence of chlamydial infection.

Infection with C. trachomatis is invariably accompanied by formation of reactive oxygen and nitrogen species that can damage DNA, proteins and cell membranes. ${ }^{21,22}$ Inflammation induces increasing cell damage, cell death and compensatory cell proliferation. This process and its influence may lead to mutagenesis. ${ }^{23,24}$ DNA damage caused by oxidative stress resulting from Chlamydia infection, ${ }^{25}$ may be one mechanism for Chlamydiainduced carcinogenesis. Chlamydia trachomatis also has an anti-apoptotic activity. ${ }^{26}$ The infection causes inflammation, necrosis, scarring and cervical hypertrophy. It has also been speculated that the immune system cells that are activated at Chlamydia infection sites may damage normal cells.

A search of the literature showed no published data on the association between $C$. trachomatis and cervical cancer or cervical intra-epithelial lesion in Nigeria. This study is therefore aimed to determine the prevalence of $\mathrm{C}$. trachomatis and the association between Chlamydia trachomatis infection and cervical intra-epithelial lesion.

\section{METHODS}

The study is a cross-sectional case control study carried out at the cytology clinic, colposcopy clinic and gynaecology clinic of the Lagos University teaching hospital.

The sample size for the study was calculated using the statistical formula by Schlesselman. ${ }^{27}$ The study participants were then selected by consecutive sampling method from the three clinics and were divided into two groups:

The case group consists of 30 women with abnormal smears seen in all the clinics and referred to the colposcopy clinic, and the control group consists of 60 women with normal Pap smear seen in the cytology clinic.
Both groups of women were offered a group health talk on cervical cancer and chlamydial infection on presentation at the cytology and colposcopy clinics. Eligible participants at the various clinics were also given information leaflets and counseled appropriately on the objectives of the study. Excluded from the study were women who were pregnant, those who have had hysterectomy done, and pre-pubertal and adolescent girls who were attending the gynaecology clinic.

For the purpose of this study, abnormal Pap smear was defined using the Bethesda classification ${ }^{28}$ as Atypical Squamous Cells of Undetermined Significance (ASCUS), Low grade Squamous Intraepithelial Lesion (LSIL), High grade Squamous Intraepithelial Lesion (HSIL), Atypical Squamous Cells High Grade (ASC-H) cannot be excluded and Atypical Glandular Cells of Undetermined Significance (AGCUS).

Information on the socio-demographics, sexual and reproductive variables were obtained using a structured interviewer-administered questionnaire. This was then followed by a sterile speculum examination and endocervical swab was collected. Women attending the cytology clinic had both Pap smear (for precancerous lesion) and endocervical swab (for Chlamydia trachomatis antigen detection test). Women who were referred to the colposcopy clinic with a positive Pap smear had only endocervical swab done for Chlamydia trachomatis antigen detection test using PCR.

The swab sample was transported in a cold-chain box to the central research laboratory of the college of medicine for analysis by Polymerase Chain Reaction (PCR) test using consensus primers targeting the Major Outer Membrane Proteins (MOMP) and plasmid of the Chlamydia trachomatis.

All quantitative data were entered in the computer and analyzed using Epi-Info statistical package (version 3.4.3). Descriptive statistics were then computed for all relevant data. The association between $\mathrm{C}$. trachomatis and intraepithelial lesion was tested using chi-square to determine the difference. All significance were reported at $\mathrm{P}<0.05$.

Ethical clearance for the study was obtained from the hospital's health research and ethics committee and written consent obtained from each participant prior to involvement in the study.

\section{RESULTS}

As shown in Table 1, a total of 90 women (30 cases and 60 controls) participated in the study. Data were completed for analysis in all of them. The age range for the cases was 25-56 years with a mean age of $37.5 \pm 5.6$ years. The age range for control was $29-71$ years with a mean age of $41.8 \pm 8.5$ years. There is no statistically significant difference in mean ages of the case and 
control groups $(\mathrm{P}=0.06)$. There were also no statistically significant differences in the parity, age at sexual debut, age at marriage and age at delivery between the case and control groups $(\mathrm{P}>0.05)$ (Table 1 and 2$)$.

Table 1: Comparison of the socio-demographic characteristics of the subjects $(n=90)$.

\begin{tabular}{|lll|}
\hline & $\begin{array}{l}\text { Cases } \\
(\mathbf{N}=30)\end{array}$ & $\begin{array}{l}\text { Control } \\
\mathbf{N}=60)\end{array}$ \\
\hline $\mathbf{N}(\boldsymbol{\%})$ & $\mathbf{N}(\boldsymbol{\%})$ \\
\hline Age (years) & & \\
\hline $20-29$ & $2(6.7)$ & $2(3.3)$ \\
\hline $30-39$ & $17(56.7)$ & $29(48.3)$ \\
\hline $40-49$ & $10(33.3)$ & $15(25.0)$ \\
\hline $50-59$ & $1(3.3)$ & $13(21.7)$ \\
\hline $60-69$ & $0(0.0)$ & $0(0.0)$ \\
\hline $70-79$ & $0(0.0)$ & $1(1.7)$ \\
\hline Level of education & \\
\hline $\begin{array}{l}\text { No formal } \\
\text { education }\end{array}$ & $6(20.0)$ & $2(3.3)$ \\
\hline Primary & $4(13.3)$ & $10(16.7)$ \\
\hline Secondary & $6(20.0)$ & $16(26.7)$ \\
\hline Post-secondary & $11(36.7)$ & $31(51.7)$ \\
\hline Non response & $3(10.0)$ & $1(1.7)$ \\
\hline Marital status & & \\
\hline Single & $3(10.0)$ & $3(5.0)$ \\
\hline Married & $23(76.7)$ & $48(80.0)$ \\
\hline Divorced & $2(6.7)$ & $2(3.3)$ \\
\hline Separated & $0(0.0)$ & $2(3.3)$ \\
\hline Widowed & $2(6.7)$ & $4(6.7)$ \\
\hline Non-response & $0(0.0)$ & $1(1.7)$ \\
\hline
\end{tabular}

Table 2: Comparison of the socio-demographic characteristics of the subjects $(n=90)$.

\begin{tabular}{|lll|}
\hline & $\begin{array}{l}\text { Cases } \\
(\mathbf{N}=30)\end{array}$ & $\begin{array}{l}\text { Control } \\
(\mathbf{N}=60)\end{array}$ \\
\hline $\mathbf{N}(\%)$ & $\mathbf{N}(\%)$ \\
\hline Religion & $20(66.7)$ & $37(61.7)$ \\
\hline Christianity & $10(33.3)$ & $22(36.7)$ \\
\hline Islam & $0(0.0)$ & $1(1.7)$ \\
\hline Non-response & 3.0 & 4.0 \\
\hline Median parity & $21.2 \pm 3.3$ & $21.5 \pm 4.5$ \\
\hline $\begin{array}{l}\text { Mean age at sexual debut } \\
\text { (Mean } \pm \text { SD) }\end{array}$ & $22.2 \pm 3.1$ & $23 \pm 4.7$ \\
\hline $\begin{array}{l}\text { Mean age at marriage } \\
\text { (Mean } \pm \text { SD) }\end{array}$ & $22.7 \pm 7.1$ & $24.0 \pm 4.7$ \\
\hline $\begin{array}{l}\text { Mean age at first delivery } \\
\text { (Mean } \pm \text { SD) }\end{array}$ & & \\
\hline
\end{tabular}

The overall prevalence of C. trachomatis among the 90 participants in this study using the PCR technique was $27.7 \%$ (Table 3 ). Three of the four women $(75 \%)$ in the age group of 25-30 years were positive for $\mathrm{C}$. trachomatis, $21 \%$ in $31-35$ years, $32.3 \%$ in $36-40,60 \%$ in 41-45 and $14.3 \%$ in $46-50$ years. No C. trachomatis was detected in those above the age of 50 years. The trend of decreasing prevalence of $\mathrm{C}$. trachomatis with age was significant $(\mathrm{P}<0.05)$. The majority of women with $\mathrm{C}$. trachomatis were in the reproductive age group of 25-45 years.

Table 3: Prevalence of Chlamydia trachomatis in study population $(n=90)$.

\begin{tabular}{|lll|}
$\begin{array}{l}\text { Age } \\
\text { (years) }\end{array}$ & $\begin{array}{l}\text { Chlamydia } \\
\text { positives }\end{array}$ & $\begin{array}{l}\text { Chlamydia } \\
\text { negatives }\end{array}$ \\
\hline $25-30$ & $3(75.0)$ & $\mathbf{N}(\%)$ \\
\hline $31-35$ & $5(21.0)$ & $19(25.0)$ \\
\hline $36-40$ & $10(32.3)$ & $21(67.7)$ \\
\hline $41-45$ & $6(60.0)$ & $4(40.0)$ \\
\hline $46-50$ & $1(14.3)$ & $6(85.1)$ \\
\hline$>50$ & $0(0.0)$ & $14(100.0)$ \\
\hline Total & $25(27.7)$ & $65(62.3)$ \\
\hline
\end{tabular}

Table 4 showed that $50 \%$ of the cases (abnormal smear) were positive for C. trachomatis, whereas, only $16.7 \%$ of the controls (normal smear) were positive for $\mathrm{C}$. trachomatis and this difference was statistically significant $\left(\mathrm{X}^{2}=10.95 ; \mathrm{P}=0.001\right)$.

Table 4: Prevalence of Chlamydia trachomatis in women with normal and abnormal smears.

\begin{tabular}{|lll|}
$\begin{array}{l}\text { C. trachomatis } \\
\text { antigen }\end{array}$ & $\begin{array}{l}\text { Cases } \\
\text { (normal smear) }\end{array}$ & $\begin{array}{l}\text { Control } \\
\text { (abnormal smear) }\end{array}$ \\
\hline Positive & $\mathbf{N}(\%)$ & $\mathbf{N})$ \\
\hline Negative & $15(50.0)$ & $10(16.7)$ \\
\hline Total & $15(50.0)$ & $50(83.3)$ \\
\hline
\end{tabular}

Odd ratio $=5.00(95 \%$ CI $1.68-15.19)$, Chi-square $=10.95, \mathrm{P}=$ 0.001

Table 5: Prevalence of Chlamydia trachomatis in women with abnormal Pap smear $(n=30)$.

\begin{tabular}{|ll|}
\hline \multicolumn{1}{|c|}{$\begin{array}{c}\text { Chlamydia } \\
\text { positive }(\mathbf{N}=15)\end{array}$} & $\begin{array}{l}\text { Chlamydia } \\
\text { negative }(\mathbf{N}=15) \\
\mathbf{N}(\%)\end{array}$ \\
\hline Age (years) & $1(50.0)$ \\
\hline $25-30 \quad 1(50.0)$ & $5(50.0)$ \\
\hline $31-35 \quad 5(50.0)$ & $6(54.6)$ \\
\hline $36-40 \quad 5(45.5)$ & $2(33.3)$ \\
\hline $41-45 \quad 4(66.7)$ & $1(100.0)$ \\
\hline $46-50 \quad 0(0.0)$ & $5(38.5)$ \\
\hline Chi-square $=2.456 ; \mathrm{P}=0.935$ \\
\hline Cervical cytology & $4(50.0)$ \\
\hline HSIL $\quad 8(61.5)$ & $3(60.0)$ \\
\hline LSIL $\quad 4(50.0)$ & $3(75.0)$ \\
\hline ASC-H $\quad 2(40.0)$ & \\
\hline ASCUS $\quad 1(25.0)$ & \\
\hline Chi-square $=1.892 ; \mathrm{P}=0.595$ & \\
\hline
\end{tabular}


Table 5 showed no statistically significant association between age of the participants and prevalence of $\mathrm{C}$. trachomatis among women with abnormal smear $(\mathrm{P}=$ 0.935). It was also shown that the prevalence of $\mathrm{C}$. trachomatis was $61.5 \%$ in women with HISL, $50 \%$ in women with LSIL, $40 \%$ in women with ASC-H and $25.0 \%$ in women with ASCUS. However, there was no statistically significant association between prevalence of C. trachomatis and cervical cytological types $\left(\mathrm{X}^{2}=1.892\right.$; $\mathrm{P}=0.595)$.

\section{DISCUSSION}

Infection by Chlamydia trachomatis has been recognized as an important public health problem. ${ }^{29}$ The WHO estimates that approximately 50 million cases of Chlamydia trachomatis infection occur per year worldwide. ${ }^{30}$ It causes a widespread spectrum of diseases including uterine-cervical lesions. ${ }^{31}$

The prevalence of $\mathrm{C}$. trachomatis in the general population in Nigeria showed ranges between $6.5 \%$ and $66.8 \%,{ }^{8-14}$ depending on the ages, groups and localities of the surveyed population. In our study, the prevalence was $27.7 \%$ which is within the quoted range in the previous studies.

The C. trachomatis infection is noted among people in the reproductive age group in this study (25-45 years) with a decreasing trend noted with age as earlier reported in various studies on Chlamydia. ${ }^{29,32}$ This is probably due to the decreased frequency of sexual activity with age thus leading to a reduction in the prevalence in the older age group.

The role of Chlamydia trachomatis in the pathogenesis of CIN remains unexplained and sometimes controversial; while some studies show no significant association between C. trachomatis and cytologically or histologically diagnosed precancerous lesion of the cervix, ${ }^{33,34}$ others have shown a significant association. $^{35,36}$

In this study, a higher prevalence of C. trachomatis (50\%) was reported among women with abnormal smear compared to women with normal cytology (16.7\%) and this difference was statistically significant $(\mathrm{OR}=10.95 ; \mathrm{P}$ $=0.001)$. This finding is in agreement with a study done in Argentina ${ }^{35}$ where a prevalence of $47 \%$ and $11 \%$ was reported in the case and control groups respectively. A similar study done in Brazil ${ }^{36}$ also showed a significantly high prevalence of $\mathrm{C}$. trachomatis among women with histologically diagnosed precancerous lesion of the cervix. However, a study in Slovenia ${ }^{33}$ and Netherlands ${ }^{34}$ did not find any significant association. The similarities observed in our study and that of the Argentina and Brazil studies may be due to the relatively high prevalence of sexually transmitted infection often reported in developing countries as opposed to the developed countries. ${ }^{37,38}$

\section{Limitations of the study}

This is a preliminary study to find out the association between Chlamydia trachomatis and precancerous lesions of the cervix using molecular biology diagnostic techniques. It would have been interesting to detect specific serotype of C. trachomatis present in precancerous lesion of the cervix; however, subtyping of Chlamydia trachomatis involves sequencing that requires special facilities (Sequencer and reagents) which are expensive and not readily available in Nigeria. The other limitations of the study were due to cost and time constraints. Selection of women with abnormal smears would have been best done histologically using colposcopy directed biopsy but for the high cost implication and also it would have been interesting to treat the identified Chlamydia cases with antibiotics and repeat the test after about six months to determine the effect of clearance of Chlamydia trachomatis infection in the study population. A larger study with grant should probably look at this aspect.

\section{CONCLUSION}

This study showed an association between Chlamydia trachomatis, a Sexually Transmitted Infection (STI), and precancerous lesions of the cervix among women in Lagos, Nigeria. This will thus necessitate a need for proper and more aggressive treatment of C. trachomatis in women diagnosed with STI. The routine screening and treatment of sexually active adolescents and women in the reproductive age group is also recommended as an indirect measure to reducing the incidence of cervical cancer in Nigeria. A larger and more robust study should however, be done in the future to properly evaluate the effect of treatment of C. trachomatis on cervical cytology.

\section{ACKNOWLEDGEMENTS}

The authors acknowledge the entire staff of the medical record department of the hospital and the resident doctors in the department of obstetrics and gynaecology for all their logistical support, without which this study would not have been possible.

\section{Funding: No funding sources \\ Conflict of interest: None declared}

Ethical approval: The study was approved by the hospital's health research and ethics committee

\section{REFERENCES}

1. Parkin DM, Bray F, Ferlay J, Pisani P. Global cancer statistics, 2002. CA Cancer J Clin. 2005;55:74-108.

2. Ferlay J, Bray F, Pisani P, Parkin D. GLOBOCAN 2002: cancer incidence, mortality and prevalence worldwide, Lyon, France IARC, 2004. Available at: http://www-dep.iarc.fr/. Accessed 12 November 2008. 
3. Sankaranarayanan R, Ferlay J. Worldwide burden of gynaecological cancer: the size of the problem. Best Pract Res Clin Obstet Gynaecol. 2006;20(2):207-22.

4. Thomas J, Ojemakinde O, Izebraye I. Current concepts in cervical carcinogenesis and new perspectives in prevention. Arch Ibadan Med. 2002;3(1):36-9.

5. Castellsague $\mathrm{X}, \mathrm{Munoz} \mathrm{N}$. Co-factors in human papillomavirus carcinogenesis - role of parity, oral contraceptives and tobacco smoking. J Nat Cancer Inst Monogr. 2003;31:20-8.

6. Koutsky LA, Holmes, KK, Critchlow CW, Stevens CE, Paavonen J, Beckman AM et al. A cohort study of the risk of cervical intraepithelial neoplasia grade 2 or 3 in relation to papillomavirus infection. $\mathrm{N} \mathrm{Engl}$ J Med. 1992;327:1272-8.

7. Nobbenhuis MA, Walboomers JM, Helmerhorst TJ, Rozendaal L, Remmink AJ, Risse EK et al. Relation of human papillomavirus status to cervical lesions and consequences for cervical cancer screening: a prospective study. Lancet. 1999;354:20-5.

8. Darougar S, Forsey T, Osoba AO, Dines RJ, Adelusi B, Coker GO. Chlamydia genital infection in Ibadan Nigeria: a sero-epidemiological survey. Br J Vener Dis. 1982;58(6):366-9.

9. Aladesanmi AF, Mumtaz G, Mabey DC. Prevalence of cervical chlamydial infection in antenatal clinics attendees in Lagos, Nigeria. Genitourin Med. 1988;65(2):130-2.

10. Amin JD, Zaria LT, El-Nafatty AU, Mai AM. Genital trachomatis infection in women in a Nigerian hospital. Genitourin Med. 1997;73:146-7.

11. Aboyeji AP, Nwabuisi C. Prevalence of sexually transmitted infection in young pregnant women in Ilorin, Nigeria. J Obstet Gynaecol. 2003;23(6):637-9.

12. Tukur J, Shittu SO, Abdul AM. A case control study of active genital Chlamydia trachomatis infection among patient with tubal infertility in Northern Nigeria. Trop Doct. 2006;36(1):14-6.

13. Azenebor AA, Egbafona NO. Association of Chlamydia trachomatis antibodies with genital contact disease in women in Benin City, Nigeria. J Trop Med \& Int Health. 2007;2(4):389-92.

14. Omo-Agboja LO, Okonofua FE, Oremu, SO, Larsen U, Bergstrom S. Association of Chlamydia trachomatis serology with tubal infertility in Nigeria women. J Obstet \& Gynaecol Res. 2007;33(5):68895.

15. Madeleine MM, Antilla T, Schnertz S, Sakku P, Leinonen M, Joseph J. Risk of cervical cancer associated with Chlamydial trachomatis antibodies by histology, HPV types and HPV co-factors. Int $\mathbf{J}$ Cancer. 2007;120(3):650-5.

16. Silins I, Ryd W, Strand A, Wadell G, Tornberg S, Hansson BG. Chlamydial trachomatis infection and persistence of human papillomavirus. Int $\mathrm{J}$ Cancer. 2005;116:110-5.

17. Norman J. Epidemiology of female genital Chlamydia trachomatis infection. Best Pract Res Clin Obstet Gynaecol. 2002;16(6):775-87.
18. Fasubaa OB, Onayade AA, Ajenifuja TO. Experience of tubal surgery for infertility at the Obafemi Awolowo teaching hospital, Ile-Ife, Nigeria. Afr J Med Med Sci. 2004;33(4):355-60.

19. Umeora OU, Mbazor JO, Okpere EE. Tubal factor infectivity in Benin City, Nigeria: Sociodemographic of patients and aetiopathogenic factors. Trop Doct. 2007;37(2):92-4.

20. Otuonye NM, Olukoya DK, Odunukwe NN, Idigbe EO, Udeaja MN, Bamidele M et al. HIV association with conventional sexually transmitted diseases in Lagos State Nigeria. West Afr J Med. 2002;21(2):153-6.

21. Oshima H, Bartsch H. Chronic infections and inflammatory processes as cancer risk factors: possible role of nitric oxide in carcinogenesis. Mutation Res. 1994;305:253-64.

22. Rosin MP, Anwar WA, Ward AJ. Inflammation, chromosomal instability, and cancer: the schistosomiasis model. Cancer Res. 1994;54:192933.

23. Parsonnet J. Helicobacter pylori and gastric adenocarcinoma. In: Parsonnet J, eds. Microbes and Malignancy. Infection as a Cause of Human Cancers. 1st ed. New York: Oxford University Press; 1999: 372-408.

24. Rosin M, Hofseth L. Schistosomiasis, bladder and colon cancer. In: Parsonnet J, eds. Microbes and Malignancy. Infection as a Cause of Human Cancers. 1st ed. New York: Oxford University Press; 1999: 313-345.

25. Mayer JM, Woods ML, Vavrin Z, Hibbs JB. Gamma interferon-induced nitric oxide production reduces Chlamydia trachomatis infectivity in McCoy cells. Infect Immun. 1993;61:491-7.

26. Fan B, Lu H, Hu H, Shi L, McClarty G, Nance D et al. Inhibition of apoptosis in Chlamydia-infected cells: blockade of mitochondrial cytochrome C release and caspase activation. J Exp Med. 1998;187: 487-96.

27. Schlesselman JJ. Sample size requirements in Cohort and case control studies of disease. Am J Epid. 1974;99(6):381-4.

28. National Cancer Institute Workshop. The 1988 Bethesda system for reporting cervical/vaginal cancer diagnoses. J Am Med Assoc. 1989;262:931.

29. World Health Organization. Sexually transmitted and other reproductive tract infections, 2005. Available at: http://www.who.int/reproductivehealth /publications/rlis.gep/rtisgep.pdf. Accessed 20 November 2007.

30. World Health Organization. Global prevalence and incidence of selected curable sexually transmitted infections. In: WHO, eds. WHO Overview and Estimates. Geneva: WHO; 2001: 1-52.

31. Wanerheit JN. Chlamydial infection. Sex Trans Dis. 1990;19:61-79.

32. Keegan H, Ryan F, Malkin A, Grriffin M, Lambkin H. Chlamydia trachomatis detection in cervical 
preservCyt specimens from an Irish urban female population. Cytopath. 2009;20:111-6.

33. Reesink-Peters N, Ossewaarde JM, Van Der Zee AG, Quint WG, Burger MP, Adriaanse AH. No association of anti-Chlamydia trachomatis antibodies and severity of cervical neoplasia. Sex Transm Infect. 2001 Apr;77(2):101-2.

34. Takac I, Gorisek B. Chlamydia trachomatis infection in women with and without CIN. Int J STD AIDS. 1999 May;10:331-3.

35. Golijow CD, Abba MC, Mouron SA, Laguen RM, Dulout FN, Smiths JS. Chlamydia trachomatis and human papilloma virus infection in cervical disease in Argentine women. Gynaecol Oncol. 2005;96(1):181-6.

36. Micheline LO, Melania MR, Paulo RES, Lucia CBA, Lucas ACB, Rafael LG. Chlamydia infection in patients with and without cervical intra epithelial lesions tested by real-time PCR versus Direct immunofluorescence. Bras J Infect Dis. 2008;12(4):324-8.

37. Molano M, Weiderpass E, Passo H, Morre SA, Ronderas M, Franceschi S et al. Prevalence and determinants of Chlamydia trachomatis infections in women from Bogota, Columbia. Sex Transm Infect. 2003;79:474-8.

38. Cecil JA, Howell MR, Tawes JJ, Gaydas JC, Mckee Jr KT, Quinn TC et al. Feature of Chlamydia trachomatis and Neisseria gonorrhoeae infection in male army recruits. J Infect Dis. 2001;184:1216-9.

DOI: $10.5455 / 2320-1770 . i j r \operatorname{cog} 20140905$

Cite this article as: Adegbesan-Omilabu MA,

Okunade KS, Oluwole AA, Gbadegesin A, Omilabu SA. Chlamydia trachomatis among women with normal and abnormal cervical smears in Lagos, Nigeria. Int J Reprod Contracept Obstet Gynecol 2014;3:501-6. 